\title{
Influence of Anoxia on Glucose Metabolism in Pancreatic Islets: Lack of Correlation between Fructose-1,6-Diphosphate and Apparent Glycolytic Flux
}

\author{
B. Hellman, L.-Å. Idahl, J. Sehlin and I.-B. Täljedal \\ Dept. of Histology, Univ. of Umeå, Umeå, Sweden
}

Received: May 12, 1975, and in revised form: July 21, 1975

\begin{abstract}
Summary. When equilibrated with $\mathrm{O}_{2}-\mathrm{CO}_{2}(95: 5)$, pancreatic islets of non-inbred $o b / o b$-mice exhibited a sigmoidal dependence of ${ }^{3} \mathrm{H}_{2} \mathrm{O}$ production on $\mathrm{D}-\left(5-{ }^{3} \mathrm{H}\right)$-glucose concentration; the rate was most sensitive to changes of glucose concentration around $5 \mathrm{mM}$ and tended to be maximum above about $15 \mathrm{mM}$ glucose. ${ }^{3} \mathrm{H}_{2} \mathrm{O}$ production from more than $5 \mathrm{mM} \mathrm{D}-\left(5-{ }^{3} \mathrm{H}\right)$-glucose was about twice as fast as the production of ${ }^{14} \mathrm{CO}_{2}$ from equimolar D-(U- $\left.{ }^{14} \mathrm{C}\right)$ glucose. Islets equilibrated with $\mathrm{N}_{2}-\mathrm{CO}_{2}$ (95:5) did not exhibit a sigmoidal dose-response curve for ${ }^{3} \mathrm{H}_{2} \mathrm{O}$ production, the process being inhibited by anoxia at glucose concentrations above $5 \mathrm{mM}$. Pieces of exocrine pancreas had a slower aerobic ${ }^{3} \mathrm{H}_{2} \mathrm{O}$ production
\end{abstract}

than the islets and showed a clear enhancement of the process during anoxia. In comparison with oxygenated islets, anoxic islets exhibited decreased concentrations of glucose-6-phosphate and increased concentrations of fructose-1,6-diphosphate. The concomitant inhibition of glycolytic flux may be due to a low lactate dehydrogenase activity in islets yielding a slow reoxidation of $\mathrm{NADH}$ and a slow phosphoglyceraldehyde oxidation under anaerobic conditions.

Key words: Anoxia, glucose metabolism, pancreatic islets, Pasteur effect.
Stimulation of insulin release by glucose may result from the production of a metabolic signal in the pancreatic B-cells [1-4]. The understanding of insulin secretion may thus be promoted by insight into the mechanisms that regulate glucose metabolism in these cells. In most other tissues glycolysis is faster during anaerobic than under aerobic conditions. This effect of oxygen, the Pasteur effect, is probably due to the phosphofructokinase being inhibited by ATP and by a fall of ADP [5]. Matschinsky et al. [6] reported the inhibitory influence of ATP on phosphofructokinase in islet extracts. We have investigated the effects of anoxia on glycolysis in the B-cell-rich islets of non-inbred $o b / o b$-mice by measuring the transmembrane transport of glucose, the islet contents of glucose-6phosphate and fructose-1,6-diphosphate and the production of ${ }^{3} \mathrm{H}_{2} \mathrm{O}$ from $\mathrm{D}-\left(5-{ }^{3} \mathrm{H}\right)$ glucose.

\section{Materials and Methods}

\section{General}

Fresh islets were isolated by free-hand microdissection [7] of pancreatic glands from adult, non-inbred $o b / o b$-mice from the Umeå colony; the isolation was performed at $2^{\circ}$ with the glands suspended in KrebsRinger bicarbonate buffer equilibrated with $\mathrm{O}_{2}-\mathrm{CO}_{2}$ (95:5). In a few experiments pieces of exocrine pancreas were taken for comparison with the islets.
Krebs-Ringer bicarbonate buffer equilibrated with $\mathrm{O}_{2}-\mathrm{CO}_{2}(95: 5)$ or $\mathrm{N}_{2}-\mathrm{CO}_{2}(95: 5)$ was used as basal medium in subsequent incubations at $37^{\circ}$. Isolated islets were subjected to preliminary incubation for 30 $\min$ at $37^{\circ}$ in the absence or presence $(5 \mathrm{mM})$ of glucose. Incubation was then continued in basal medium supplemented with D-glucose as required; the sugar was added as pure $\alpha$-D-glucose, but this was done long before the incubation to allow equlibration of the $\alpha$ and $\beta$ anomers. The detailed incubation procedure depended on the aim of the experiment as follows.

\section{${ }^{3} \mathrm{H}_{2} \mathrm{O}$ Production}

By using the method described by Ashcroft et al. [2], the production of ${ }^{3} \mathrm{H}_{2} \mathrm{O}$ from $\mathrm{D}-\left(5-{ }^{3} \mathrm{H}\right)$ glucose was measured as an index of the combined flux through the glycolytic and phosphogluconate pathways. Batches of 2 islets were incubated at $37^{\circ}$ in $15 \mu \mathrm{l}$ of medium labelled with $\mathrm{D}-\left(5-{ }^{3} \mathrm{H}\right)$ glucose $(0.3-10.0 \mathrm{Ci} /$ $\mathrm{mol})$; the glucose concentration varied between experiments as stated in the Results section. The medium was kept in a small polythene tube placed in a glass vial of the type used in liquid-scintillation counting; the glass vial contained $500 \mu 1$ double-distilled water. After $60 \mathrm{~min}, 5 \mu \mathrm{l}$ of $0.2 \mathrm{M} \mathrm{HCl}$ was added to the incubation medium to stop metabolism, and incubation was continued overnight to allow equilibration of the ${ }^{3} \mathrm{H}_{2} \mathrm{O}$ produced with the water in the outer vial. After removing the polythene tube with the 
islets, the radioactivity of the water was measured in a liquid-scintillation spectrometer. External standards were prepared by adding $5 \mu \mathrm{l}$ of incubation medium to $500 \mu \mathrm{l}$ of water. The recovery, as judged by adding ${ }^{3} \mathrm{H}_{2} \mathrm{O}$ to incubation tubes without islets, was about $85 \%$.

\section{${ }^{14} \mathrm{CO}_{2}$ Production}

Batches of 2 islets were incubated for $60 \mathrm{~min}$ at $37^{\circ}$ in medium containing various concentrations of D-glucose and labelled with $\mathrm{D}-\left(\mathrm{U}_{-}{ }^{14} \mathrm{C}\right)$ glucose $(0.6-17.0 \mathrm{Ci} / \mathrm{mol})$. After arresting metabolism with $0.1 \mathrm{M} \mathrm{HCl},{ }^{14} \mathrm{CO}_{2}$ was collected in hyamine and measured in a liquid-scintillation spectrometer as previously described [8].

\section{D-Glucose Transport}

Batches of 6 islets were incubated for $45 \mathrm{sec}$ at $37^{\circ}$ in medium containing 3 or $20 \mathrm{mMD}$-glucose as well as $0.15 \mathrm{mM}$ L-glucose; the medium was labelled with $\mathrm{D}-\left(6-{ }^{3} \mathrm{H}\right)$ glucose $(5.0$ or $0.8 \mathrm{Ci} / \mathrm{mol})$ and $\mathrm{L}-\left(1-{ }^{14} \mathrm{C}\right)$ glucose $(51.6 \mathrm{Ci} / \mathrm{mol})$. After freeze-drying and weighing (see below), the islets were dissolved in hyamine and their content of ${ }^{3} \mathrm{H}$ and ${ }^{14} \mathrm{C}$ simultaneously measured in a liquid-scintillation spectrometer. Because L-glucose apparently does not enter the B-cells, the uptake of D-glucose in excess of the space occupied by L-glucose was used as an index of D-glucose transmembrane transport $[9,10]$.

\section{Islet Content of Glucose-6-Phosphate and Fructo- se-1,6-Diphosphate}

Batches of 2 islets were incubated for $60 \mathrm{~min}$ at $37^{\circ}$ in $15 \mu \mathrm{l}$ of medium containing $1 \mathrm{mg}$ of bovine serum albumin/ml and various concentrations of D-glucose. The same incubation vials as in the ${ }^{3} \mathrm{H}_{2} \mathrm{O}$ production experiments were used. After freeze-drying and weighing, the islets were placed in $15 \mathrm{mM} \mathrm{HCl}(1 \mu \mathrm{l}$ acid/ $\mu \mathrm{g}$ dry tissue) and held at $60^{\circ}$ for $20 \mathrm{~min}$. The extract was assayed for glucose-6-phosphate and fructose-1,6-disphosphate plus triose phosphates as described by Matschinsky [11].

\section{Weighing of Islets}

After incubation with isotopes the islets were placed on pieces of aluminium foil and, with the aid of a micropipette, freed of as much contaminating fluid as possible. In the glucose transport measurements particular care was taken to complete this procedure within $5 \mathrm{sec}$. The islets were then plunged into melting isopentane, freeze-dried overnight $\left(-40^{\circ}, 0.1 \mathrm{~Pa}\right)$, and weighed on a quartz-fibre balance.In previous radioactive tracer studies the treatment of islets with $\mathrm{HCl}$ before weighing did not significantly alter the dry weight, although the mean value decreased by some $20 \%$ [12]. More extensive control experiments in the present investigation showed, however, that the effect of acid treatment is statistically significant. Because of difficulties in estimating its magnitude exactly, reported values are uncorrected for this islet weight loss. Since it apparently occurs during the first $60 \mathrm{~min}$ of treatment, it should affect neither the comparison of ${ }^{14} \mathrm{CO}_{2}$ with ${ }^{3} \mathrm{H}_{2} \mathrm{O}$ data, nor the comparison of oxygenated with anoxic islets. In substrate measurements, islets were frozen and freeze-dried while remaining in the incubation vial. The fluffy dry substance of medium was then carefully brushed off from the islets under a stereomicroscope before weighing on the quartz-fibre balance.

\section{Chemicals}

The sources of chemical were as follows. The Radiochemical Centre, Amersham, England: D- $\left(5-{ }^{3} \mathrm{H}\right)-$ glucose, D- $\left(6-{ }^{3} \mathrm{H}\right)$ glucose, $\mathrm{D}-\left(\mathrm{U}-{ }^{14} \mathrm{C}\right)$ glucose, and ${ }^{3} \mathrm{H}_{2} \mathrm{O}$. New England Nuclear Chemicals, Frankfurt/Main, Germany: L- $\left(1-{ }^{14} \mathrm{C}\right)$ glucose. Boehringer Mannheim, Mannheim, Germany: glucose-6-phosphate and fructose-1,6-diphosphate as well as cofactors and enzymes for substrate measurements. British Drug House, Poole, England: D-glucose. Sigma Chemical Co., St. Louis, Mo., U.S.A.: bovine serum albumin (fraction V). Double-distilled water was used throughout.

\section{Results}

\section{${ }^{3} \mathrm{H}_{2} \mathrm{O}$ Production}

Fig. 1 shows the effects of D- $\left(5-{ }^{3} \mathrm{H}\right)$ glucose concentration on ${ }^{3} \mathrm{H}_{2} \mathrm{O}$ production in islets equilibrated with $\mathrm{O}_{2}-\mathrm{CO}_{2}$ (95:5) or $\mathrm{N}_{2}-\mathrm{CO}_{2}(95: 5)$. The dependence of ${ }^{14} \mathrm{CO}_{2}$ production on $\mathrm{D}-\left(\mathrm{U}-{ }^{14} \mathrm{C}\right)$ glucose concentration is also given. In oxygenated islets both the ${ }^{3} \mathrm{H}_{2} \mathrm{O}$ and the ${ }^{14} \mathrm{CO}_{2}$ productions exhibited sigmoidal dose-response relationships in the glucose concentration range of 1-30 mM. At high glucose concentrations about twice as much ${ }^{3} \mathrm{H}_{2} \mathrm{O}$ as ${ }^{14} \mathrm{CO}_{2}$ was formed; at concentrations below $10 \mathrm{mM}$ the ratio was greater. Islets equilibrated with $\mathrm{N}_{2}$ did not show a sigmoidal, but rather a hyperboloid, dose-response relationship for the ${ }^{3} \mathrm{H}_{2} \mathrm{O}$ production. Anoxia inhibited the formation of ${ }^{3} \mathrm{H}_{2} \mathrm{O}$ at glucose concentrations above $5 \mathrm{mM}$ but apparently had no effect at 1 or $3 \mathrm{mM}$ glucose. 
Virtually no ${ }^{14} \mathrm{CO}_{2}$ was produced in islets equilibrated with $\mathrm{N}_{2}-\mathrm{CO}_{2}$.

The results in Fig. 1 were obtained after the islets had been subjected to preliminary incubation without substrate during anoxia. However, the inhibitory effect of anoxia on ${ }^{3} \mathrm{H}_{2} \mathrm{O}$ production was also observed after preliminary incubation in the presence of $5 \mathrm{mM}$ glucose and in medium equilibrated with $\mathrm{O}_{2}$ (Table 1 ).

As shown in Table 2, $20 \mathrm{mM}$ mannoheptulose significantly inhibited the production of ${ }^{3} \mathrm{H}_{2} \mathrm{O}$ in oxygenated as well as in anoxic islets; the effect was greater in the presence of $\mathrm{O}_{2}$ than during anoxia. In mannoheptulose-treated islets, production of ${ }^{3} \mathrm{H}_{2} \mathrm{O}$ was significantly greater in the absence than in the presence of oxygen. A comparison of Table 2 with Fig. 1 also shows that the rate of ${ }^{3} \mathrm{H}_{2} \mathrm{O}$ production in pieces of exocrine pancreas was much lower than that in islets and was significantly stimulated by anoxia.

\section{Islet Content of Glucose-6-Phosphate and of Fructo- se-1,6-Diphosphate Plus Triose Phosphates}

The effect of glucose on the concentration in islets of glucose-6-phosphate or of fructose-1,6-diphosphate plus triose phosphates is shown in Fig. 2. In oxygenated islets both metabolic pools increased with glucose up to $39 \mathrm{mM}$, the highest glucose concentration tested. During anoxia the concentration of glucose-6phosphate was decreased at all glucose concentrations; a dependence on glucose, however, was still seen. The level of fructose-1,6-diphosphate plus triose phosphates in anoxic islets showed no dependence on glucose above $1 \mathrm{mM}$, but already at that low glucose concentration had reached a maximum. The

Table 1. Effects of pretreatment with oxygen and glucose on the subsequent metabolic response to anoxia. After preliminary incubation for 30 min in non-radioactive medium, the islets were incubated with $9 \mathrm{mM} \mathrm{D-}\left(5-{ }^{3} \mathrm{H}\right)$ glucose $(1.1 \mathrm{Ci} / \mathrm{mol})$ for $60 \mathrm{~min}$. The gas phase and the presence of glucose during the preliminary incubation as well as the gas phase during the subsequent incubation with radioactive glucose were as indicated. Rates of ${ }^{3} \mathrm{H}_{2} \mathrm{O}$ production are given as mean values \pm S.E.M. for the numbers of experiments stated in parentheses. Differences between groups were-t-tested:groups 4 and 1 $P<0.01$; groups 3 and $2, P<0.001$; groups 5 and $2, P<0.01$

\begin{tabular}{|c|c|c|c|c|}
\hline \multirow[t]{2}{*}{ Group } & \multicolumn{2}{|c|}{ Pretreatment } & \multicolumn{2}{|c|}{ Incubation with $\mathrm{D}-\left(5-{ }^{3} \mathrm{H}\right)$ glucose } \\
\hline & Gas phase & $\begin{array}{l}\text { Glucose } \\
\text { concn. } \\
\text { (mM) }\end{array}$ & Gas phase & $\begin{array}{l}\text { Production of }{ }^{3} \mathrm{H}_{2} \mathrm{O} \\
\text { (mmol/h per kg dry } \\
\text { wt.) }\end{array}$ \\
\hline $\begin{array}{l}1 \\
2 \\
3 \\
4 \\
5\end{array}$ & $\begin{array}{l}\mathrm{O}_{2}-\mathrm{CO}_{2} \\
\mathrm{O}_{2}-\mathrm{CO}_{2} \\
\mathrm{O}_{2}-\mathrm{CO}_{2} \\
\mathrm{~N}_{2}-\mathrm{CO}_{2} \\
\mathrm{~N}_{2}-\mathrm{CO}_{2}\end{array}$ & $\begin{array}{l}0 \\
5 \\
5 \\
0 \\
5\end{array}$ & $\begin{array}{l}\mathrm{O}_{2}-\mathrm{CO}_{2} \\
\mathrm{O}_{2}-\mathrm{CO}_{2} \\
\mathrm{~N}_{2}-\mathrm{CO}_{2} \\
\mathrm{~N}_{2}-\mathrm{CO}_{2} \\
\mathrm{~N}_{2}-\mathrm{CO}_{2}\end{array}$ & $\begin{array}{l}45.2 \pm 4.2(6) \\
47.6 \pm 1.8(11) \\
29.2 \pm 2.4(6) \\
29.7 \pm 1.8(6) \\
34.9 \pm 2.5(5)\end{array}$ \\
\hline
\end{tabular}

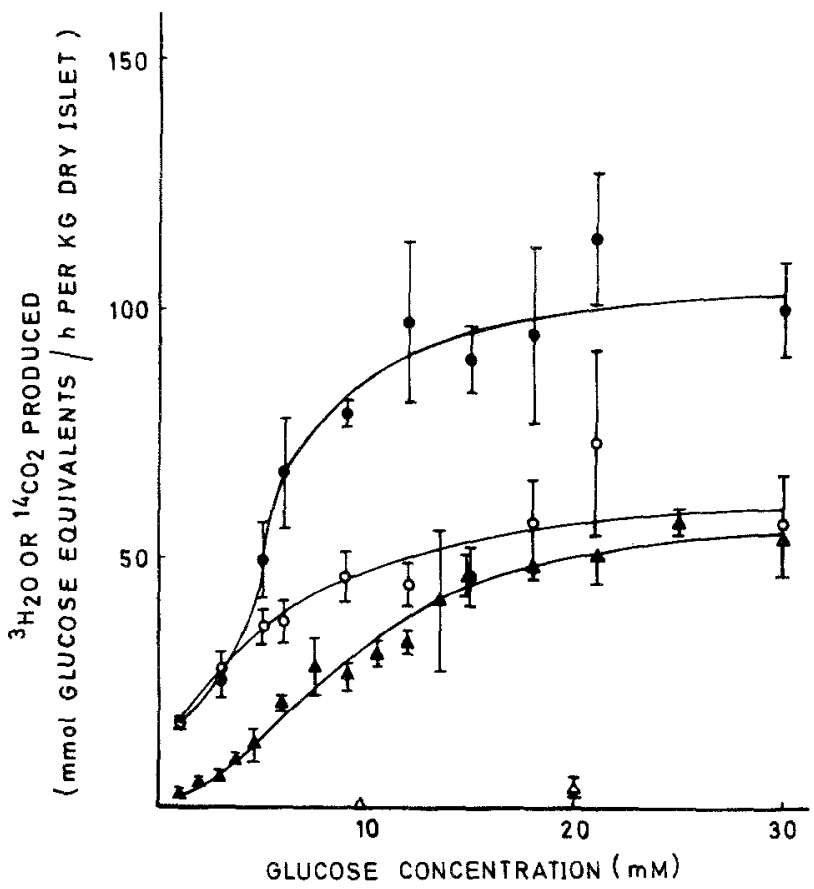

Fig 1. Production of ${ }^{3} \mathrm{H}_{2} \mathrm{O}$ from $\mathrm{D}-\left(5-{ }^{3} \mathrm{H}\right)$ glucose and of ${ }^{14} \mathrm{CO}_{2}$ from $\mathrm{D}-\left(\mathrm{U}-{ }^{14} \mathrm{C}\right)$ glucose in islets incubated with or without oxygen. Islets were incubated for $60 \mathrm{~min}$ in media containing various concentrations of $\mathrm{D}-\left(5-{ }^{3} \mathrm{H}\right)$ glucose $(\bullet, 0)$ or $\mathrm{D}-\left(\mathrm{U}-{ }^{14} \mathrm{C}\right)$ glucose $(\boldsymbol{\Delta}, \Delta)$ and equilibrated with $\mathrm{O}_{2}-\mathrm{CO}_{2}(\bullet, \Delta)$ or $\mathrm{N}_{2}-\mathrm{CO}_{2}(\circ, \Delta)$. They had first been subjected to preliminary incubation for $30 \mathrm{~min}$ in the absence of glucose under the same gas phase as used during the subsequent incubation with radioactive sugar. Amounts of ${ }^{3} \mathrm{H}_{2} \mathrm{O}$ or ${ }^{14} \mathrm{CO}_{2}$ produced are given as mmol of glucose equivalents metabolized $/ \mathrm{kg}$ dry weight of islets. Each point represents the mean of 2-10 different experiments. Bars denote \pm S. E. M.

Table. 2. Pasteur effects in exocrine pancreas and in islets exposed to mannoheptulose. Islets or pieces of exocrine pancreas were incubated for 60 min in media which contained $D-\left(5-{ }^{3} H\right)$ glucose $(1.1$ or 0.5 $\mathrm{Ci} / \mathrm{mol}$ ) and $\mathrm{D}$-mannoheptulose and were equilibrated with $\mathrm{O}_{2}-\mathrm{CO}_{2}$ or $\mathrm{N}_{2}-\mathrm{CO}_{2}$ as indicated. All islets and pieces of exocrine pancreas had first been subjected to 30 min of preliminary incubation in the $a b$ sence of glucose under the gas phase indicated. Rates of ${ }^{3} \mathrm{H}_{2} \mathrm{O}$ production are given as mean values $\pm S . E . M$. for the numbers of experiments stated in parentheses. Differences between groups were t-tested: groups 1 and $3, P<0.001$; groups 2 and $4, P<0.001$; groups 3 and $4, P<0.001$; groups 5 and $6, P<0.02$

\begin{tabular}{lcccc}
\hline $\begin{array}{l}\text { Group Glucose in } \\
\text { medium } \\
(\mathrm{mM})\end{array}$ & $\begin{array}{c}\text { Mannoheptulose } \\
\text { in medium }(\mathrm{mM})\end{array}$ & $\begin{array}{l}\text { Gas phase Production } \\
\text { of }{ }^{3} \mathrm{H}_{2} \mathrm{O} \\
\text { (mmol/h per } \\
\text { kg dry wt.) }\end{array}$ \\
\hline Islets & & & & \\
1 & 9 & 0 & $\mathrm{O}_{2}-\mathrm{CO}_{2}$ & $52.1 \pm 2.3(7)$ \\
2 & 9 & 0 & $\mathrm{~N}_{2}-\mathrm{CO}_{2}$ & $41.2 \pm 1.7(8)$ \\
3 & 9 & 20 & $\mathrm{O}_{2}-\mathrm{CO}_{2}$ & $18.1 \pm 1.6(7)$ \\
4 & 9 & 20 & $\mathrm{~N}_{2}-\mathrm{CO}_{2}$ & $31.6 \pm 0.9(8)$ \\
Exocrine & & & & \\
pancreas & & & & \\
5 & 20 & 0 & $\mathrm{O}_{2}-\mathrm{CO}_{2}$ & $19.8 \pm 2.4(7)$ \\
6 & 20 & 0 & $\mathrm{~N}_{2}-\mathrm{CO}_{2}$ & $28.9 \pm 1.2(7)$
\end{tabular}






Fig. 2. Glucose-6-phosphate and fructose-1,6-diphosphate plus triose phosphates in islets incubated with or without oxygen. Islets were incubated for 60 min in media containing various concentrations of D-glucose and equilibrated with $\mathrm{O}_{2}-\mathrm{CO}_{2}(\bullet)$ or $\mathrm{N}_{2}-\mathrm{CO}_{2}(0)$ : They had first been subjected to preliminary incubation for $30 \mathrm{~min}$ in the absence of D-glucose under the same gas phase as used during the subsequent incubation with sugar. The points show contents of glucose-6-phosphate (left panel) or fructose-1,6-diphosphate plus triose phosphates (right panel) and represent the mean values of 5-6 different experiments. Bars denote \pm S. E. M.

Table 3. Ratio of fructose-1,6-diphosphate plus triose phosphates to glucose-6-phosphate in anoxic and oxygenated islets. Data refer to the same experiments as in Fig. 2. For each individual batch of islets, the ratio between the concentration of fructose-1,6-diphosphate plus triose phosphates and that of glucose-6-phosphate was calculated. The ratios at various glucose concentrations are given as the arithmetic means of repeated experiments. Values in parentheses indicate range and number of batches of islets in each group. The differences between oxygenated and anoxic islets were tested by the two-sided Wilcoxon rank sum test: ${ }^{*} P=0.05 ; * * P<0.01 . N I=$ Not investigated

\begin{tabular}{lll}
\hline $\begin{array}{l}\text { Glucose in } \\
\text { medium }(\mathrm{mM})\end{array}$ & $\mathrm{O}_{2}-\mathrm{CO}_{2}$ & $\mathrm{~N}_{2}-\mathrm{CO}_{2}$ \\
\hline 1 & 1.08 & \\
\hline & $(0.41-1.91 ; 4)$ & $2.92^{*}$ \\
5 & 1.62 & $(1.90-3.54 ; 5)$ \\
& $(0.47-2.70 ; 5)$ & $(1.87-4.64 ; 5)$ \\
12 & 1.18 & 2.57 \\
& $(0.74-1.78 ; 5)$ & $(1.23-3.80 ; 5)$ \\
18 & 1.24 & $2.55^{* *}$ \\
& $(0.54-1.76 ; 6)$ & $(1.86-3.45 ; 6)$ \\
25 & 1.08 & $\mathrm{NI}$ \\
& $(0.76-1.76 ; 6)$ & \\
32 & 1.23 & $1.86^{* *}$ \\
& $(0.68-1.67 ; 6)$ & $(1.53-2.23 ; 6)$ \\
39 & 1.06 & $\mathrm{NI}$ \\
& $(0.96-1.14 ; 5)$ & \\
\hline
\end{tabular}

Table 4. D-glucose transport in pancreatic islets. Islets were incubated for $45 \mathrm{sec}$ at $37^{\circ}$ in media containing $0.15 \mathrm{mM} \mathrm{L}-\left(1-{ }^{14} \mathrm{C}\right)$ glucose $(51.6 \mathrm{Ci} / \mathrm{mol})$ as well as 3 or $20 \mathrm{mM} \mathrm{D}-\left(6-{ }^{3} \mathrm{H}\right)$ glucose $(5.0$ or 0.8 $\mathrm{Ci} / \mathrm{mol})$. They had first been subjected to preliminary incubation for 30 min in the absence of glucose. The gas phase during preliminary and subsequent incubations was $\mathrm{O}_{2}-\mathrm{CO}_{2}$ or $\mathrm{N}_{2}-\mathrm{CO}_{2}$ as indicated. Islet uptake of D-glucose in excess of the space occupied by $L$-glucose is given as mean values $\pm S . E$. M. for 5 different experiments

\begin{tabular}{lcr}
\hline $\begin{array}{l}\text { D-glucose in } \\
\text { medium }(\mathrm{mM})\end{array}$ & Gas phase & $\begin{array}{l}\text { D-glucose transported } \\
\text { (mmol/kg dry weight) }\end{array}$ \\
\hline 3 & & $2.47 \pm 0.34$ \\
3 & $\mathrm{O}_{2}-\mathrm{CO}_{2}$ & $3.01 \pm 0.42$ \\
20 & $\mathrm{~N}_{2}-\mathrm{CO}_{2}$ & $18.28 \pm 2.06$ \\
20 & $\mathrm{O}_{2}-\mathrm{CO}_{2}$ & $17.56 \pm 0.93$ \\
\hline
\end{tabular}


latter was the same as that observed with the highest glucose concentrations in oxygenated islets. Thus, when incubated with physiological glucose concentrations, anoxic islets had a clearly increased pool of fructose-1,6-diphosphate plus triose phosphates.

Since glucose-6-phosphate and fructose-1,6-diphosphate plus triose phosphates were measured in the same islets, the ratio between the two metabolic pools could be calculated for each batch of islets. Table 3 shows that at each glucose concentration investigated, the ratio of fructose-1,6-diphosphate plus triose phosphates to glucose-6-phosphate was higher in the anoxic than in the oxygenated islets.

\section{Glucose Transport}

Table 4 shows that the rate of $\mathrm{D}$-glucose transport was not demonstrably different in anoxic as compared to oxygenated islets.

\section{Discussion}

The dependence of ${ }^{3} \mathrm{H}_{2} \mathrm{O}$ production on $\mathrm{D}-\left(5-{ }^{3} \mathrm{H}\right)$ glucose concentration and the proportion between ${ }^{3} \mathrm{H}_{2} \mathrm{O}$ and ${ }^{14} \mathrm{CO}_{2}$ productions are in fair agreement with previous data on collagenase-isolated islets of normal mice [2]. The novel finding that anoxia inhibited the formation of ${ }^{3} \mathrm{H}_{2} \mathrm{O}$ cannot be attributed to mobilization of $\mathrm{B}$-cell glycogen with a resulting dilution of ${ }^{3} \mathrm{H}$ in glucose-6-phosphate. When islets of $o b / o b$-mice have been incubated for $60 \mathrm{~min}$ with 17 $\mathrm{mM}$ glucose, they contain only about $10 \mathrm{mmol}$ of glucosyl residues in glycogen $/ \mathrm{kg}$ dry weight [13]; total mobilization of such a glycogen store would account for less than $20 \%$ of the inhibition of ${ }^{3} \mathrm{H}_{2} \mathrm{O}$ production. More important, in several experiments the inhibitory effect of anoxia was observed when the islets had been preliminarily incubated without glucose; under such conditions the B-cells become markedly depleted of glycogen so that virtually none would remain to be mobilized by subsequent anoxia [13].

Anoxia is known to stimulate glycolysis in a variety of cells [5]; this 'Pasteur effect' is shown here for mouse exocrine pancreas. The present failure to detect a Pasteur effect in the islets does not rule out that such an effect might be demonstrated under other conditions, e. g. under more moderate hypoxia. Nevertheless, the clearly different behaviour between the exocrine and endocrine pancreas when subjected to the same incubation procedures may reflect the metabolic specialization of the B-cell as a glucostat. According to current thinking, the Pasteur effect is due to inhibition of phosphofructokinase by ATP and by a fall of ADP [5]. The phosphofructokinase in B-cells appears to be no exception to the rule: in islet extracts the enzyme is inhibited by ATP [6]. Our demonstration of a decreased ratio of glucose-6-phosphate to fructose-1,6-diphosphate plus triose phosphates during anoxia may reflect the activation of phosphofructokinase in intact islets. However, in view of the glycolytic flux being inhibited, the substrate measurements are not conclusive for an activation of the phosphofructokinase. The inhibition of the glycolytic flux, in spite of glucose transport being apparently unaffected, indicates a partial blockade of some step(s) in the glycolytic pathway of the anoxic islets. The fall of glucose-6-phosphate suggests that glucose phosphorylation was retarded, probably because of a shortage of ATP. In addition, because the concentration of fructose-1,6-diphosphate plus triose phosphates was increased in the anoxic islets, it seems necessary to postulate at least one point of inhibition distal to these metabolites. This point may be the phosphoglyceraldehyde dehydrogenase reaction, which could have been inhibited because of anoxia impeding the re-oxidation of NADH. Ischemia promptly increases the islet content of NADH [14], and in experiments with azaserine [15] and nitrosomethylureas [16] a fall of NAD was associated with inhibited glucose oxidation in the islets.

The islets under study have a lactate dehydrogenase, the subunit composition of which was described as favourable for anaerobic lactate production and $\mathrm{NADH}$ re-oxidation; its maximum activity in homogenates was estimated to be at least $4650 \mathrm{mmol} / \mathrm{h}$ per $\mathrm{kg}$ [17]. However, these high values may grossly exaggerate the activity in living $\mathrm{B}$-cells. In intact rat islets the rate of $\mathrm{D}-\left(\mathrm{U}-{ }^{14} \mathrm{C}\right)$ glucose conversion to ${ }^{14} \mathrm{C}$-labelled lactate was only about $15 \mathrm{mmol}$ of glucose/h per kg dry weight at a glucose concentration of 17 $\mathrm{mM}$ [18]. A comparison of the ${ }^{3} \mathrm{H}_{2} \mathrm{O}$ and ${ }^{14} \mathrm{CO}_{2}$ production curves in Fig. 1 suggests that in intact islets of non-inbred $o b / o b$-mice the rate of lactate production from glucose is at the most $50 \mathrm{mmol}$ of glucose $(100$ $\mathrm{mmol}$ of lactate)/h per $\mathrm{kg}$ dry weight; this value is close to the maximum rate of anoxic ${ }^{3} \mathrm{H}_{2} \mathrm{O}$ production. The inhibition of glycolysis by anoxia may thus in part occur because the lactate dehydrogenase of intact islets has a low activity in comparison with the capacity of the rest of the glycolytic pathway. We are attracted by this hypothesis because it is consistent with the observation of a Pasteur effect in pieces of exocrine pancreas, a tissue that has both a slower aerobic glycolysis (Table 1) and a much higher lactate dehydrogenase activity than the islets [17].

Although a low lactate dehydrogenase activity may explain why anoxia inhibited the production of ${ }^{3} \mathrm{H}_{2} \mathrm{O}$ 
at high glucose concentrations, it remains to be explained why no Pasteur effect was observed with 1 or $3 \mathrm{mM}$ glucose: in contrast to the rate of ${ }^{3} \mathrm{H}_{2} \mathrm{O}$ production, the concentration of fructose-1,6-diphosphate plus triose phosphates in anoxic islets was already at its maximum with $1 \mathrm{mM}$ glucose. The full understanding of these data may require studies on the time course of intermediate changes during anoxia and on the effects of anoxia on the adenine nucleotide system. Such studies may also help to explain the puzzling observation that mannoheptulose was a more effective inhibitor of glycolytic flux in oxygenated as compared with anoxic islets. An unexpected behaviour of mannoheptulose is not without precedent, since Ashcroft et al. [19] found that the compound markedly inhibited glucose oxidation and yet was without effect on the production of lactate in isolated mouse islets.

Acknowledgements. This work was supported by the Swedish Medical Research Council grant $12 \times-562$.

\section{References}

1. Grodsky, G. M., Batts, A. A., Bennett, L. L., Vcella, C., McWilliams, N. B., Smith, D. F.: Effects of carbohydrates on secretion of insulin from isolated rat pancreas. Amer. J. Physiol. 205, 638-644 (1963)

2. Ashcroft, S. J. H., Weerasinghe, L. C. C., Bassett, J. M., Randle, P. J.: The pentose cycle and insulin release in mouse pancreatic islets. Biochem. J. 126, 525-532 (1972)

3. Ashcroft, S. J. H., Weerasinghe, L. C. C., Randle, P. J.: Interrelationship of islet metabolism, adenosine triphosphate content and insulin release. Biochem. J. 132, 223-231 (1973)

4. Hellman, B., Idahl, L.- $\AA$, Lernmark, A, Sehlin, J., Täljedal, I.-B.: The pancreatic $\beta$-cell recognition of insulin secretagogues. VIII. Comparisons of glucose with glyceraldehyde isomers and dihydroxyacetone. Arch. Biochem. Biophys. 162, 448-457 (1974)

5. Krebs, H. A.: The Pasteur effect and the relations between respiration and fermentation. In: Essays in biochemistry, vol. 8 (eds. Campbell, P. N., F. Dickens), pp. 1-34. London: Academic Press 1972

6. Matschinsky, F. M., Rutherford, C. R., Ellerman, J. E.: Accumulation of citrate in pancreatic islets of obese hyperglycemic mice. Biochem biophys. Res. Commun. 33, 855-862 (1968)
7. Hellerström, C.: A method for the microdissection of intact pancreatic islets of mammals. Acta endocr. (Kbh.) 45, 122-132 (1964)

8. Hellman, B., Sehlin, J., Täljedal, I.-B.: Effects of glucose and other modifiers of insulin secretion on the oxidative metabolism of amino acids. Biochem. J. 123, 513-521 (1971)

9. Hellman, B., Sehlin, J., Täljedal, I.-B.: Evidence for mediated transport of glucose in mammalian pancreatic $\beta$-cells. Biochim. biophys. Acta (Amst.) 241, 147-154 (1971)

10. Hellman, B., Idahl, L.-Å, Lernmark, Å., Sehlin, J., Täljedal, I.-B.: The pancreatic $\beta$-cell recognition of insulin secretagogues. IX. Effects of calcium and sodium on glucose metabolism and insulin release. Biochem. J. 138, 33-45 (1974)

11. Matschinsky, F. M.: Quantitative histochemistry of glucose metabolism in the islets of Langerhans. In: Recent advances in quantitative histo- and cytochemistry (eds. U. C. Dubach, U. Schmidt), pp. 143-179. Bern: Hans Huber Publishers 1971

12. Hellman, B., Idahl, L.-Å, Lernmark, $\AA$, Sehlin, J., Täljedal, I.-B.: Iodoacetamide-induced sensitization of the pancreatic $\beta$-cells to glucose stimulation. Biochem. J. 132, 775-789 (1973)

13. Hellman, B., Idahl, L.- $\AA$ : On the functional significance of the pancreatic $\beta$-cell glycogen. In: The structure and metabolism of the pancreatic islets, (eds. S. Falkmer, B. Hellman, I.-B. Täljedal), pp. 253-261. Oxford: Pergamon Press 1970

14. Berne, C., Brolin, S. E., Ågren, A.: Influence of ischemia on the levels of reduced pyridine nucleotides in the pancreatic islets. Horm. Metab. Res. 5, 141-142 (1973)

15. Deery, D. J., Taylor, K. W.: Effects of azaserine and nicotinamide on insulin release and nicotinamide-adenine dinucleotide metabolism in isolated rat islets of Langerhans. Biochem. J. 134, 557-563 (1973)

16. Gunnarson, R., Berne, C., Hellerström, C.: Cytotoxic effects of streptozotocin and $N$-nitrosomethylurea on the pancreatic B cells with special regard to the role of nicotinamide-adenine dinucleotide. Biochem. J. 140, 487-494 (1974)

17. Hellman, B., Täljedal, I.-B.: Quantitative studies on isolated pancreatic islets of mammals. Activity and heterogeneity of lactate dehydrogenase in obese-hyperglycemic mice. Endocrinology 81, 125-131 (1967)

18. Reese, A. C., Landau, B. R., Craig, J. W., Gin, G., Rodman, H. M.: Glucose metabolism by rat pancreatic islets in vitro. Metab. clin. Exp. 22, 467-472 (1973)

19. Ashcroft, S. J. H., Hedeskov, C. J., Randle, P. J.: Glucose metabolism in mouse pancreatic islets. Biochem. J. 118, 143-154 (1970)

Prof. B. Hellman

Univ. of Umeå

Dept. of Histology

S-90187 Umeå 6

Sweden 